\title{
ANALISIS FAKTOR-FAKTOR YANG MEMPENGARUHI PERMINTAAN BARANG PANGAN DAN SANDANG PADA PERUSAHAAN RITEL X KARAWANG
}

\author{
${ }^{1}$ Santi Pertiwi H.S.S.E.,M.M \\ ${ }^{2}$ Eva Fauziah \\ Jurusan Manajemen Fakultas Bisnis dan Ilmu Sosial Universitas Buana Perjuangan \\ Karawang \\ santi.pertiwi@ubpkarawang.ac.id \\ evafauziah.eff@gmail.com
}

\begin{abstract}
ABSTRAK
Perusahaan Ritel X merupakan perusahaan ritel yang terkenal di Indonesia. Salah satunya yaitu perusahaan Ritel $X$ di Karawang. Penelitian ini menggunakan data primer yang didapatkan dari masyarakat Kota Karawang dengan cara membagikan kuesioner di beberapa tempat di Kota Karawang.

Variabel bebas yaitu harga barang tersebut, harga barang pengganti, harga barang pelengkap, pendapatan, distribusi pendapatan, selera serta variabel terikat yaitu permintaan kebutuhan pangan dan sandang pada perusahaan Ritel X Karawang. Analisis data menggunakan regresi linear berganda, uji asumsi klasik dan uji hipotesis, kemudian data diolah dengan menggunakan Eviews 10 dan SPSS 24.

Hasil penelitian ini menunjukkan bahwa variabel selera (cita rasa) berpengaruh secara positif dan signifikan terhadap permintaan kebutuhan pangan dan sandang pada perusahaan Ritel X Karawang. Variabel harga barang tersebut berpengaruh secara negatif dan tidak signifikan. Variabel harga barang pengganti berpengaruh secara positif dan tidak signifikan. Variabel harga barang pelengkap berpengaruh secara positif dan tidak signifikan. Variabel pendapatan berpengaruh secara negatif dan tidak signifikan. Variabel distribusi pendapatan berpengaruh secara positif dan tidak signifikan. Adapun secara keseluruhan variabel bebas berpengaruh sebesar 51,8\%, sedangkan sisanya 48,2\% dijelaskan oleh variabel residual yaitu variabel yang berada di luar model, yang tidak dimasukkan ke dalam model.
\end{abstract}

Kata kunci: Permintaan Kebutuhan Pangan dan Sandang, Harga Barang Tersebut, Harga Barang Pengganti, Harga Barang Pelengkap, Pendapatan, Distribusi Pendapatan, dan Selera.

\begin{abstract}
Retail company $X$ is a well-known retail company in Indonesia. On of them is retail company $X$ in Karawang. This research uses primary data obtained from the people of Karawang City by distributing questionnaires in several places in the city of Karawang.

The independent variable is the price of the item, the price of substitute goods, the price of complementary goods, income, income distribution, taste and the dependent variable is the
\end{abstract}


demand for food and clothing needs in retail company $X$ Karawang. Data analysisi using multiple linear regression, classical assumption test and hypothesis testing, then data processed by using SPSS 24 and Eview 10.

The results of this study indicate that the variable tastes positively and significantly affect the demand for food and clothing needs in retail company $X$ Karawang. The price variable of the item has a negative and insignificant effect. The variable price of substitute goods has a positive and insignificant effect. Variabel price of complementary goods has a positive and insignificant effect. The income variable has a negative and insignificant effect. Income distribution variables have a positive and insignificant effect. As for the overall independent variable has an effect of 51,8\%, while the remaining 48,2\% is explained by the residual variable that is the variable that is outside the model, which is not included in the model.

Key word: Demand for Food and Clothing Needs, The Price of The Item, The Price of Substitute Goods, The Price of Complementary Goods, Income, Income Distribution and Taste.

\section{PENDAHULUAN}

Pengembangan infrastruktur di Jabodetabek tak hanya mengurai kemacetan, tetapi juga membantu penyebaran pertumbuhan ekonomi. Kawasan -kawasan penyangga Jakarta terus memunculkan primadona baru, yang di antaranya tumbuh sebagai kota industri sekaligus mendorong terciptanya area hunian ideal salah satu nya adalah Karawang. Dikenal sebagai kota industri, Karawang memiliki kawasan industri terluas di Indonesia, bahkan di Asia Tenggara, dengan total luas lahan industri mencapai 13,718 hektare atau 7,85 persen dari luas Kabupaten Karawang. Berdasarkan data dari situs Pemerintah Kabupaten Karawang, jumlah industri besar dan industri kecil hingga 2014 sebanyak 9.979 industri. Mencakup industri otomotif, elektronik, tekstil, baja, manufaktur, farmasi, dan lain-lain. Lebih dari 50 persennya merupakan penanaman modal asing (PMA). Karawang disiapkan pemerintah sebagai kawasan industri modern melalui penerbitan Keppres Nomor 53 Tahun 1989 tentang Pengembangan Kawasan Industri. Ditambah dengan prospek pembangunan bandara internasional dan kereta cepat Jakarta - Bandung. Karawang semakin menjanjikan sebagai kawasan yang menawarkan aksesibilitas tinggi. (adv.kompas, 24 Januari 2017).

Saat ini, menurut data Himpunan Kawasan Industri Indonesia (HKI) setidaknya terdapat sembilan kawasan industri besar yakni Karawang International Industrial City (KIIC), Bukit Indah City, Kawasan Industri Surya Cipta, Karawang Jabar Industrial Estate, Podomoro Industrial Park, Kawasan Industri Kujang, Karawang Industri Mitrakarawang, GT Tech Park Karawang, dan Artha Industrial Hill. (Kompas.com - 21/06/2016). Dengan pertambahan jumlah perusahaan di kawasan industri karawang tentu diikuti jumlah tenaga kerja, yang jumlah pekerja ini akan melakukan pemindahan tempat tinggal dan secara otomatis kondisi itu akan membawa dampak peningkatan kebutuhan sandang, pangan, dan papan. 
Berikut merupakan tabel 1.1 Jumlah Usaha Menurut Klasifikasi Lapangan Usaha di Kabupaten Karawang tahun 2015.

Tabel 1.1

Jumlah Usaha Menurut Klasifikasi Lapangan Usaha di Kabupaten Karawang, 2015

\begin{tabular}{|c|c|c|c|}
\hline & Jenis Lapangan Usaha* & $\begin{array}{c}\text { Jumlah Usaha } \\
\text { (2) }\end{array}$ & $\begin{array}{c}\text { Jumlah Pegawai } \\
\text { (3) }\end{array}$ \\
\hline 1 & Industri Pengolahan & 438 & 160.651 \\
\hline 2 & Informasi dan Komunikasi & 2 & 10 \\
\hline 3 & Jasa Kesehatan dan Kegiatan Sosial & 24 & 2.316 \\
\hline 4 & Jasa Keuangan dan Asuransi & 87 & 3.385 \\
\hline 5 & Jasa Pendidikan & 2 & 33 \\
\hline 6 & $\begin{array}{l}\text { Jasa Persewaaan, dan Sewa Guna Usaha Tanpa Hak Opsi, } \\
\text { Ketenagakerjaan, Agen Perjalanan dan Penunjang Usaha lainnya }\end{array}$ & 149 & 34.712 \\
\hline 7 & Jasa Profesional, Ilmiah dan Teknis & 11 & 880 \\
\hline 8 & Kegiatan Jasa Lainnya & 2 & 55 \\
\hline 9 & Kesenian, Hiburan dan Rekreasi & 3 & 449 \\
\hline 10 & Konstruksi & 10 & 1.380 \\
\hline 11 & $\begin{array}{l}\text { Pengadaan Air, Pengelolaan Sampah dan Daur Ulang, } \\
\text { Pembuangan dan Pembersihan Limbah dan Sampah }\end{array}$ & 4 & 307 \\
\hline 12 & Pengadaan Listrik, Gas, Uap/Air Panas dan Udara Dingin & 10 & 749 \\
\hline 13 & Penyediaan Akomodasi dan Penyediaan Makan Minum & 46 & 1.473 \\
\hline 14 & $\begin{array}{l}\text { Perdagangan Besar dan Eceran; Reparasi dan Perawatan Mobil dan } \\
\text { Sepeda Motor }\end{array}$ & 130 & 7.169 \\
\hline 15 & Pertambangan dan Penggalian & 3 & 253 \\
\hline 16 & Pertanian, Kehutanan dan Perikanan & 6 & 619 \\
\hline 17 & Real Estat & 18 & 1.960 \\
\hline 18 & Transportasi dan Pergudangan & 17 & 927 \\
\hline \multirow[t]{2}{*}{19} & Industri Kecil & 9.290 & 9.627 \\
\hline & Karawang & 10.252 & 226.955 \\
\hline
\end{tabular}

Keterangan: *) Kategori Klasifikasi Industri menurut Dinas Perindustrian Kab. Karawang

Sumber: Publikasi Karawang dalam Angka 2016

Kebutuhan primer atau biasa yang disebut dengan kebutuhan pokok manusia dibagi menjadi tiga macam, yaitu : sandang, papan dan pangan. Kebutuhan sandang adalah kebutuhan pakaian yang diperlukan manusia untuk kehidupan sehari - hari. Pakaian diperlukan untuk melindungi tubuh dari panas dan dingin. Sedangkan kebutuhan pangan atau biasa yang disebut dengan makan adalah kebutuhan paling utama bagi makhluk hidup. Makanan dan minuman bertujuan untuk menghasilkan tenaga dan nutrisi. Tenaga dan 
nutrisi yang diperoleh berguna untuk melalukan berbagai aktifitas sehari - hari. Makanan yang sehat dan bergizi membantu pertumbuhan manusia baik otak maupun badan.

Kebutuhan akan pangan dan sandang merupakan kebutuhan yang sangat penting bagi manusia. Setiap individu manusia akan mengutamakan pemenuhan kebutuhan dasar primer dan kebutuhan sekundernya. Sudah sangat banyak penyedia barang pangan dan sandang ini mulai dari toko-toko kelontong tradisional sampai ritel modern. Saat ini persaingan dunia ritel di Indonesia sudah mulai semakin ketat, di Karawang sudah mulai menjamur Mall, Supermarket, minimarket-minimarket modern. Sementara disisi lain, warung-warung dan toko-toko klontong tradisional semakin lama malah semakin terpojok bahkan sampai hampir menghilang ditinggalkan para pembelinya. Para konsumen meninggalkan warung-warung atau toko-toko klontong trasidional dikarenakan beberapa faktor diantaranya miskin pengelolaan manjemen, barang-barang kurang lengkap, harga yang tidak bersaing, toko dengan mindset (kumuh) dan lain sebagainya.

Saat ini kebutuhan pangan dan papan tidak hanya menjadi sebuah kebutuhan primer untuk memenuhi kebutuhan, tetapi tanpa kita sadari sudah menjadi salah satu gaya hidup masyarakat Karawang. Mayoritas masyarakat Karawang akan pergi ke mall, supermarket, atau minimarket bukan hanya untuk membeli kebutuhan pangan atau sandang tetapi juga untuk bersosialisasi dengan orang lain, atau bahkan untuk memperoleh hiburan. Beberapa perusahaan ritel Nasional yang bergerak dalam bidang ini di Karawang misalnya Carrefour, Transmart, Hypermart, Giant, Superindo dan lain-lain.

Berikut merupakan jumlah penduduk Karawang pada tahun 2010-2015

Tabel 1.2

Jumlah penduduk Kabupaten Karawang

\begin{tabular}{|c|c|}
\hline Tahun & Jumlah \\
\hline 2010 & 2.127 .791 \\
\hline 2011 & 2.168 .710 \\
\hline 2012 & 2.207 .181 \\
\hline 2013 & 2.225 .383 \\
\hline 2014 & 2.250 .120 \\
\hline 2015 & 2.273 .579 \\
\hline
\end{tabular}

Sumber : BPS Provinsi Jabar, BPS Kabupaten/ Kota di Jawa Barat

Dari banyaknya perusahaan ritel yang ada di Karawang menjadi alternatif untuk konsumen dalam menentukan pilihan dalam melakukan pembelajaan untuk kebutuhan 
pangan dan sandang tersebut. Salah satu pilihannya yaitu Perusahaan Ritel X. Perusahaan Ritel X memulai kegiatannya di Indonesia sejak 1998. Hingga saat ini, sebanyak 84 gerai tersebar di seluruh Indonesia yang berada di bawah merek Perusahaan Ritel X dan Perusahaan Ritel X pada 28 Kabupaten/Kota di Indonesia yaitu Medan, Batam, Palembang, Jakarta, Serang, Depok, Bekasi, Tanggerang, Cikarang, Karawang, Cibinong, Bandung, Cirebon, Yogyakarta, Solo, Pekalongan, Semarang, Madiun, Surabaya, Jember, Malang, Makassar, Denpasar, Singaraja, Pontianak, Mojokerto, Magelang dan Pasuruan. Perusahaan Ritel X bermitra dengan lebih dari 4.000 pemasok dari seluruh Indonesia, yang 70\% dari jumlah tersebut termasuk dalam kategori Usaha Kecil dan Menengah (UKM). Melalui Perusahaan Ritel X, para pemasok ini dapat memberikan akses kepada pelanggan di seluruh Indonesia. 90\% produk yang ditawarkan Perusahaan Ritel X merupakan produk lokal. Sejak bulan November 2012, Perusahaan Ritel X di Indonesia sudah dimiliki 100\% sahamnya oleh salah satu putra terbaik bangsa Indonesia melalui CT Corp. Secara resmi, mulai tanggal 16 Januari 2013, PT Perusahaan Ritel X Indonesia berganti nama perusahaan menjadi Perusahaan Ritel X Retail Indonesia. (8/12/2013 detikFinance).

Alasan Perusahaan Ritel X membuka perusahaanya di Karawang adalah wilayah Karawang merupakan daerah penyangga ibu kota yang terus berkembang pesat dengan banyaknya kawasan perumahan dan industri. Remodelling terhadap gerai Perusahaan Ritel $\mathrm{X}$ di Karawang ini merupakan respons atas masukan pelanggan yang menginginkan tempat berbelanja yang lebih luas dan nyaman dengan pilihan produk yang lengkap," ujar Hendrik Adrianto, Head of External Communication and Corporate Social Responsibility PT Trans Retail Indonesia dalam siaran pers, Jumat (6/12/2013).

Perubahan signifikan yang dilakukan Perusahaan Ritel X antara lain memperluas area penjualan menjadi 4.442 meter dari sebelumnya 3.370 meter; menambah jumlah kasir; memperbesar area parkir kendaraan roda 4 dan roda 2; serta bergabungnya beberapa tenant terkemuka di area shopping mall. Selain itu, peritel modern ini juga melakukan peningkatan kualitas pelayanan dengan menawarkan berbagai produk segar unggulan, produk perlengkapan rumah tangga, mainan, dan sepeda yang lebih lengkap.

Saat ini pertumbuhan sektor Ritel 2017 lebih rendah dari 2016, menurut ketua Umum Asosiasi Pelaku Ritel Indonesia atau Aprindo Roy Nicholas Mandey mengatakan pertumbuhan ritel hingga semester I 2017 3,7 persen. Ia memprediksi hingga akhir tahun akan mencapai 7,5 sampai 8 persen. Perilaku belanja yang tadinya dengan keranjang ukuran besar, sekarang konsumen belanja dengan ukuran keranjang yang kecil, karena sudah banyak layanan jemput barang. Orang sekarang sudah tidak lagi ke toko, cukup pesan online 
atau dengan jasa jemput barang yang tersedia dalam aplikasi transportasi daring. Pola belanja yang berubah itu membuat costumer tidak belanja bulanan, tp belanja secukupnya sesuai kebutuhan saja, industri sekarang dari data 2016 masih 1,4 persen transaksi online dari pada total offline. Jadi retail online itu dengan total lebih kurang 97,3 user internet hanya 8,7 juta yang transaksi, data terakhir hampir 9 juta transaksi. Kalau transaksi ritel dalam setahun mencapai 5 juta maka total yang pemasukan baru sekitar 1,4 persen dari US\$ 350 miliar market cap offline ritel di Indonesia menurut GRD Global Retail Development. "Kalau 1,4 persen berarti baru sekitar US\$ 4,9 juta online. ( TEMPO, 17/10/17). Berikut data kunjungan konsumen dan penjualan tahun 2015-2017

Tabel 1.3

Data Kunjungan Konsumen dan Penjualan Tahun 2015-2017

\begin{tabular}{|r|r|c|}
\hline Tahun & Konsumen & Sales \\
\hline 2015 & 1.410 .683 & Rp. 219.771.918.629 \\
\hline 2016 & 1.139 .674 & Rp. 182.688.910.030 \\
\hline 2017 & 887.198 & Rp. 141.471.437.019 \\
\hline
\end{tabular}

Sumber : Perusahaan Ritel X Karawang, 2017

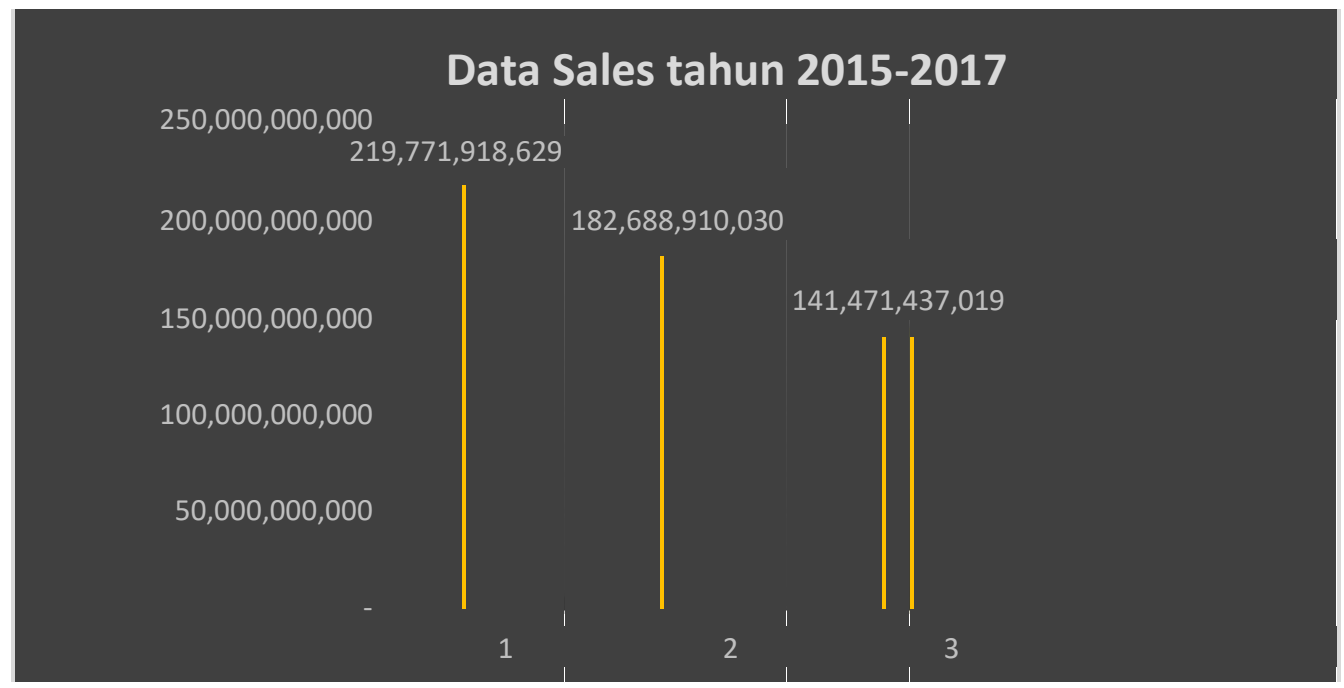

Grafik 1.1

Data Sales tahun 2015-2017

Sumber : Perusahaan Ritel X Karawang 2017 


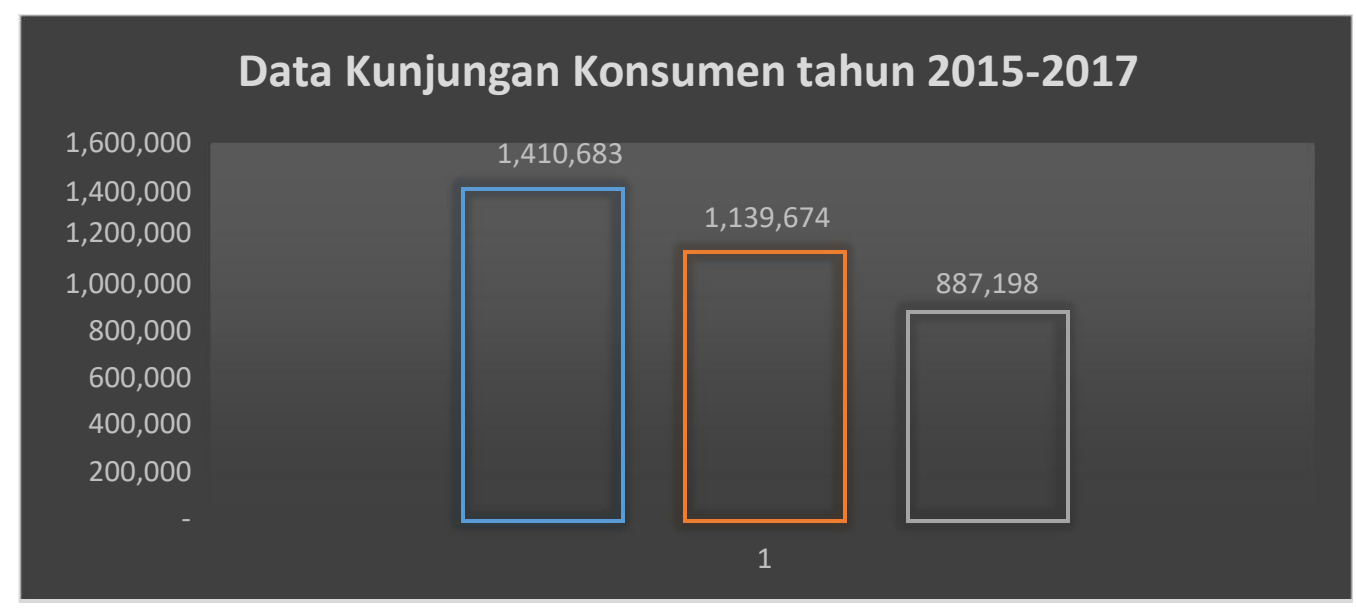

\section{Grafik 1.2}

Data Kunjungan Konsumen tahun 2015-2017

Sumber : Perusahaan Ritel X Karawang 2017

Dari data di atas tahun 2015-2017 jumlah kunjungan dan penjualannya mengalami penurunan, di tahun 2016 penurunan jumlah konsumen yaitu sebanyak 271.009 orang dengan total penjualan mengalami penurunan sebanyak Rp. 37.008.599, sedangkan untuk penuunan di tahun 2017 jumlah konsumen sebanyak 252.476 orang dengan jumlah penurunan penjualan yaitu sebesar Rp. 41.217.473.011.

Berdasarkan hal tersebut maka menjadi hal yang menarik untuk peneliti untuk melakukan penelitian hal-hal apa yang menyebabkan konsumen melakukan permintaan terhadap Perusahaan Ritel X. Dan tertuang dalam judul “Analisis Faktor-faktor yang Mempengaruhi Permintaan Pangan dan Sandang pada Perusahaan Ritel X Karawang".

\section{KERANGKA PEMIKIRAN TEORITIS DAN PERUMUSAN HIPOTESIS}

\section{Pengaruh Harga Barang tersebut Terhadap Permintaan Pangan dan Sandang}

Harga barang mempengaruhi kuantitas permintaan barang tersebut, sifat keterkaitan antara permintaan terhadap suatu barang dan harga tersebut telah dijelaskan dalam hukum permintaan. Naik turunnya harga barang atau jasa akan mempengaruhi banyak atau sedikitnya terhadap barang yang diminta. Kuantitas akan menurun ketika harganya meningkat dan kuantitas yang diminta meningkat ketika harganya menurun, dapat dikatakan bahwa kuantitas yang diminta berhubungan negatif (negatively related) dengan harga.

\section{Pengaruh Harga Barang Pengganti Terhadap Permintaan Pangan dan Sandang}


Harga barang pengganti atau disebut juga barang subtitusi (barang yang bisa menggantikan fungsi barang lain). Naik turunnya harga barang pengganti akan mempengaruhi banyak atau sedikitnya terhadap barang yang diminta.

\section{Pengaruh Harga Barang Pelengkap Terhadap Permintaan Pangan dan Sandang}

Harga barang pelengkap atau disebut juga barang komplementer (barang yang selalu digunakan bersama-sama dengan barang lainnya). Hubungan antara harga barang pelengkap dengan permintaan pangan dan sandang itu sendiri jelas. Kenaikan harga barang pelengkap akan berpengaruh berkurangnya tingkat permintaan pangan dan sandang.

\section{Pengaruh Pendapatan Terhadap Permintaan Pangan dan Sandang}

Hubungan antara tingkat pendapatan yang berpengaruh terhadap tingkat permintaan sandang dan pangan bahwa semakin besar tingkat pendapatan maka pergerakan permintaan juga cenderung akan meningkat.

\section{Pengaruh Distribusi Pendapatan Terhadap Permintaan Pangan dan Sandang}

Sejumlah pendapatan masyarakat yang tertentu besarnya akan menimbulkan corak permintaan masyarakat yang berbeda apabila pendapatan tersebut diubah corak distribusinya.

\section{Pengaruh Selera Terhadap Permintaan Pangan dan Sandang}

Cita rasa atau selera masyarakat terhadap suatu barang merupakan kepuasan individu yang berbeda-beda. Cita rasa mempunyai pengaruh yang cukup besar terhadap keinginan masyarakat untuk membeli barang-barang.

Kerangka pemikiran Analisis Faktor-faktor yang Mempengaruhi Permintaan Barang Pangan dan Sandang pada Perusahaan Ritel X Karawang dapat digambarkan sebagai berikut:

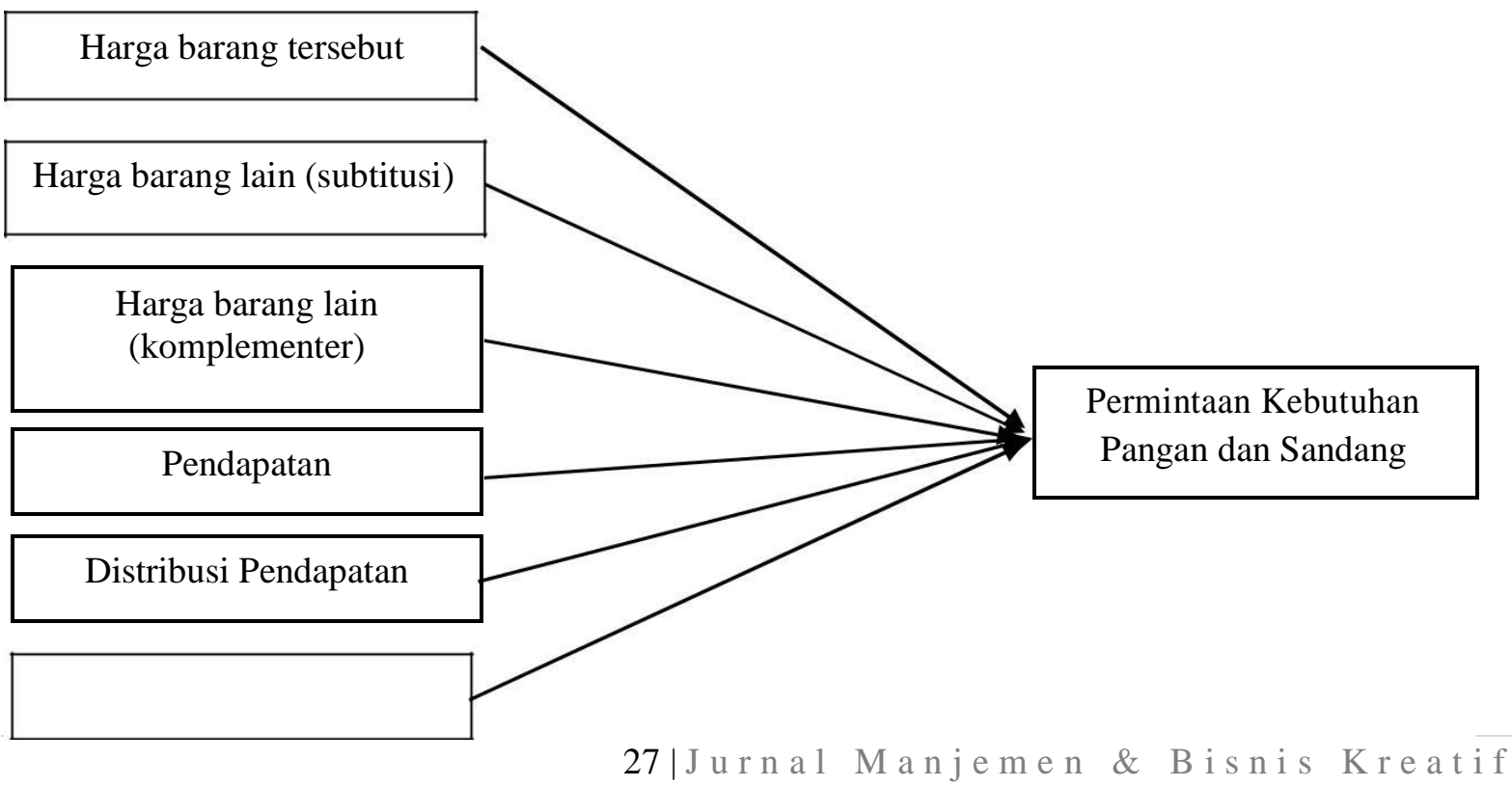


Dari bagan diatas pengujian dengan analisis data akan dilakukan untuk melihat bagaimana pengaruh variabel X (independen) terhadap Y (dependen). Dalam penelitian ini hipotesis yang dapat ditarik adalah:

1. Diduga harga barang tersebut berpengaruh negatif dan signifikan terhadap permintaan barang pangan dan sandang pada perusahaan ritel x Karawang.

2. Diduga harga barang lain (pengganti) berpengaruh negatif dan signifikan terhadap permintaan barang pangan dan sandang pada perusahaan ritel x Karawang.

3. Diduga harga barang lain (komplementer) berpengaruh negatif dan signifikan terhadap permintaan barang pangan dan sandang pada perusahaan ritel x Karawang.

4. Diduga pendapatan berpengaruh positif dan signifikan terhadap permintaan barang pangan dan sandang pada perusahaan ritel x Karawang.

5. Diduga distribusi pendapatan berpengaruh positif dan signifikan terhadap permintaan barang pangan dan sandang pada perusahaan ritel x Karawang.

6. Diduga Selera berpengaruh positif dan signifikan terhadap permintaan barang pangan dan sandang pada perusahaan ritel x Karawang.

\section{METODE PENELITIAN}

\section{Variabel Penelitian dan Definisi Operasional Variabel}

Dalam penelitian ini digunakan dua jenis variabel penelitian, yaitu variabel terikat (dependent) dan variabel bebas (independent).

\section{Variabel Terikat (Dependent Variabel)}

Dalam penelitian ini variabel dependent yang digunakan adalah permintaan pangan dan sandang pada perusahaan Ritel X Karawang. Permintaan kebutuhan pangan dan sandang ini adalah jumlah pembelian kebutuhan pangan dan sandang oleh konsumen Perusahaan Ritel X Karawang.

\section{Variabel Bebas (Independent Variabel)}

1. Harga Barang itu Sendiri

2. Harga Barang Pengganti

3. Harga Barang Pelengkap

4. Pendapatan

5. Distribusi Pendapatan

6. Selera 


\section{Populasi dan Sampel}

Populasi dalam penelitian ini adalah konsumen Perusahaan Ritel X yang berada di Karawang. Dikarenakan jumlah populasi yang besar, maka digunakan teknik sampling, hal ini dikarenakan apabila meneliti semua individu dalam populasi, akan memakan biaya yang sangat besar dan juga membutuhkan waktu yang lama. Dengan meneliti sebagaian dari populasi, diharapkan bahwa hasil yang diperoleh akan dapat menggambarkan sifat populasi yang bersangkutan. Sampel adalah sebagian dari jumlah dan karakteristik yang dimiliki oleh populasi (Sugiyono,2002).

Ukuran sampel dihitung berdasarkan rumus Slovin (Nasir,2004) yaitu sebagai berikut:

$$
\mathrm{n}=\mathrm{N} /(1+\mathrm{N} . \mathrm{e} 2) \quad \text { atau } \quad \mathrm{n}=\mathrm{N} /(\mathrm{N} . \mathrm{d} 2+1)
$$

dimana:

$$
\begin{array}{ll}
\mathrm{n} & =\text { jumlah sampel } \\
\mathrm{N} & =\text { ukuran populasi }
\end{array}
$$

$\mathrm{E}$ atau $\mathrm{d}=$ persentase kelonggaran karena ketidaktelitian dan kesalahan dalam pengambilan sampel

$$
\begin{aligned}
& \mathrm{n}=92226 /\left(1+92226.0,1^{2}\right) \\
& =92226 / 923.26 \\
& =99,89 \text { (dibulatkan 100) }
\end{aligned}
$$

Berdasarkan perhitungan menggunakan rumus Slovin besaran sampel dalam penelitian ini berjumlah 99,89 (dibulatkan 100) responden dengan persentase kelonggaran karena ketidaktelitian dan kesalahan dalam pengambilan sampel $10 \%$. Sehingga penelitian ini menggunakan total sampel sebesar 100 responden.

\section{Metode Analisis}

Penelitian ini menggunakan analisis regresi linier berganda. Model regresi linier berganda memungkinkan untuk memasukan lebih dari satu variable predictor. Kemudian uji asumsi klasik yang meliputi uji multikolineritas, uji autokolerasi, uji heterokedesitas dan uji normalitas.

Model dalam penelitian ini adalah sebagai berikut:

$\mathrm{Y}=\alpha .+\beta 1 \mathrm{Xl}+\beta 2 \mathrm{X} 2+\beta 3 \mathrm{X} 3+\beta 4 \mathrm{X} 4+\beta 5 \mathrm{X} 5+\beta 6 \mathrm{X} 6+\mathrm{u}$

Dimana :

$\mathrm{Y} \quad=$ Permintaan kebutuhan pangan dan sandang 
$\alpha \quad=$ Intercept

$\beta 1=$ Koefisien regresi harga barang tersebut

$\mathrm{X} 1=$ Harga barang tersebut

$\beta 2=$ Koefisien regresi harga barang subtitusi

$\mathrm{X} 2=$ Harga barang subtitusi

$\beta 3=$ Koefisien regresi harga barang komplementer

X3 = Harga barang komplementer

$\beta 4=$ Koefisien regresi pendapatan

X4 = Pendapatan

$\beta 5=$ Koefisien distribusi pendapatan

X5 = Distribusi pendapatan

B6 = Koefisien cita rasa (selera)

X6 = Selera

$\mathrm{u} \quad=$ Error term

\section{HASIL PENELITIAN DAN PEMBAHASAN Deskripsi Sampel Penelitian}

\section{Harga Barang Tersebut}

Dari tabel 1 dapat diketahui terdapat 100 orang responden, dan 22 orang responden dengan frekuensi 22 persen diantaranya mengatakan ya atau akan tetap berbelanja di perusahaan Ritel X walau harga barang tersebut naik. Dan 78 orang responden atau dengan frekuensi 78 persen mengatakan tidak atau tidak akan berbelanja di perusahaan Ritel X jika harga barang tersebut naik.

Tabel 1

Distribusi Responden Berdasarkan Harga Barang Tersebut

\begin{tabular}{|c|c|c|}
\hline \multirow{2}{*}{$\begin{array}{c}\text { Harga Barang } \\
\text { Tersebut }\end{array}$} & \multicolumn{2}{|c|}{ Responden } \\
\cline { 2 - 3 } & Frekuensi & Persentase(\%) \\
\hline Ya & 22 & 22 \\
\hline Tidak & 78 & 78 \\
\hline Jumlah & $\mathbf{1 0 0}$ & $\mathbf{1 0 0}$ \\
\hline
\end{tabular}

\section{Harga Barang Pengganti}

Dari tabel 2 dapat diketahui terdapat 100 orang responden, dan 21 orang responden dengan frekuensi 21 persen diantaranya mengatakan ya atau akan tetap berbelanja di perusahaan Ritel X walau harga barang pengganti naik. Dan 79 orang responden atau dengan 
frekuensi 79 persen mengatakan tidak atau tidak akan berbelanja di perusahaan Ritel X jika harga barang pengganti naik.

Tabel 2

Distribusi Responden Berdasarkan Harga Barang Pengganti

\begin{tabular}{|c|c|c|}
\hline \multirow{2}{*}{$\begin{array}{c}\text { Harga Barang } \\
\text { Pengganti }\end{array}$} & Frekuensi & Persentase(\%) \\
\cline { 2 - 3 } & 21 & 21 \\
\hline Ya & 79 & 79 \\
\hline Tidak & $\mathbf{1 0 0}$ & $\mathbf{1 0 0}$ \\
\hline Jumlah & & \\
\hline
\end{tabular}

\section{Harga Barang Pelengkap}

Dari tabel 3 dapat diketahui terdapat 100 orang responden, dan 24 orang responden dengan frekuensi 24 persen diantaranya mengatakan ya atau akan tetap berbelanja di perusahaan Ritel X walau harga barang pelengkap naik. Dan 76 orang responden atau dengan frekuensi 76 persen mengatakan tidak atau tidak akan berbelanja di perusahaan Ritel X jika harga barang pelengkap naik.

Tabel 3

Distribusi Responden Berdasarkan Harga Barang Pelengkap

\begin{tabular}{|c|c|c|}
\hline \multirow{2}{*}{$\begin{array}{c}\text { Harga Barang } \\
\text { Pelengkap }\end{array}$} & \multicolumn{2}{|c|}{ Responden } \\
\cline { 2 - 3 } & Frekuensi & Persentase(\%) \\
\hline Ya & 24 & 24 \\
\hline Tidak & 76 & 76 \\
\hline Jumlah & $\mathbf{1 0 0}$ & $\mathbf{1 0 0}$ \\
\hline
\end{tabular}

\section{Pendapatan}

Dari tabel 4 dapat diketahui terdapat 100 orang responden, dan 17 orang responden dengan frekuensi 17 persen diantaranya mengatakan ya atau akan tetap berbelanja di perusahaan Ritel X walau pendapatan menurun. Dan 83 orang responden atau dengan frekuensi 83 persen mengatakan tidak atau tidak akan berbelanja di perusahaan Ritel X jika pendapatan menurun.

Tabel 4

Distribusi Responden Berdasarkan Pendapatan

\begin{tabular}{|c|c|c|}
\hline \multirow{2}{*}{ Pendapatan } & \multicolumn{2}{|c|}{ Responden } \\
\cline { 2 - 3 } & Frekuensi & Persentase(\%) \\
\hline Ya & 17 & 17 \\
\hline Tidak & 83 & 83 \\
\hline Jumlah & $\mathbf{1 0 0}$ & $\mathbf{1 0 0}$ \\
\hline
\end{tabular}

\section{Distribusi Pendapatan}

Dari tabel 5 dapat diketahui terdapat 100 orang responden, dan 24 orang responden dengan frekuensi 24 persen diantaranya mengatakan ya atau akan tetap berbelanja di 
perusahaan Ritel X walau tingkat distribusi pendapatan menurun. Dan 76 orang responden atau dengan frekuensi 76 persen mengatakan tidak atau tidak akan berbelanja di perusahaan Ritel X jika tingkat distribusi pendapatan menurun.

Tabel 5

Distribusi Responden Berdasarkan Distribusi Pendapatan

\begin{tabular}{|c|c|c|}
\hline \multirow{2}{*}{$\begin{array}{c}\text { Distribusi } \\
\text { Pendapatan }\end{array}$} & Frekuensi & Persentase(\%) \\
\cline { 2 - 3 } & 24 & 24 \\
\hline Ya & 76 & 76 \\
\hline Tidak & $\mathbf{1 0 0}$ & $\mathbf{1 0 0}$ \\
\hline Jumlah & &
\end{tabular}

\section{Selera}

Dari tabel 6 dapat diketahui terdapat 100 orang responden, dan 26 orang responden dengan frekuensi 26 persen diantaranya mengatakan ya atau akan tetap berbelanja di perusahaan Ritel X walau pada saat barang yang diinginkan lebih murah ditempat lain. Dan 74 orang responden atau dengan frekuensi 74 persen mengatakan tidak atau tidak akan berbelanja di perusahaan Ritel X jika barang yang diinginkan lebih murah ditempat lain.

Tabel 6

Distribusi Responden Berdasarkan Selera

\begin{tabular}{|c|c|c|}
\hline \multirow{2}{*}{ Selera } & \multicolumn{2}{|c|}{ Responden } \\
\cline { 2 - 3 } & Frekuensi & Persentase(\%) \\
\hline Ya & 26 & 26 \\
\hline Tidak & 74 & 74 \\
\hline Jumlah & $\mathbf{1 0 0}$ & $\mathbf{1 0 0}$ \\
\hline
\end{tabular}

\section{Pembahasan Hasil Penelitian}

Pengujian hipotesis dalam penelitian ini dilakukan dengan menggunakan model analisis regresi linier. Namun sebelumnya akan terlebih dahulu dilakukan pengujian terhadap penyimpangan asumsi klasik.

\section{Uji Asumsi Klasik}

Uji asumsi klasik perlu dilakukan karena dalam model regresi perlu memperhatikan adanya penyimpangan-penyimpangan atas asumsi klasik, karena pada hakekatnya jika asumsi klasik tidak dipenuhi maka variabel-variabel yang menjelaskan akan menjadi tidak efisien.

\section{Uji Normalitas}

Uji normalitas bertujuan untuk menguji apakah model regresi, data yang digunakan mempunyai distribusi normal atau tidak. Untuk mendeteksi hal ini digunakan uji jarque- 
Berra, uji menggunakan distribusi probabilitas. Justifikasi lainnya untuk uji ini adalah dengan membandingkan nilai J-B hitung dengan $x^{2}$ tabel, apabila $\mathrm{J}$-B hitung $<x^{2}$ tabel maka residual u, terdistribusi normal (Gujarati,1995). Hasil uji normalitas dapat dilihat pada gambar berikut:

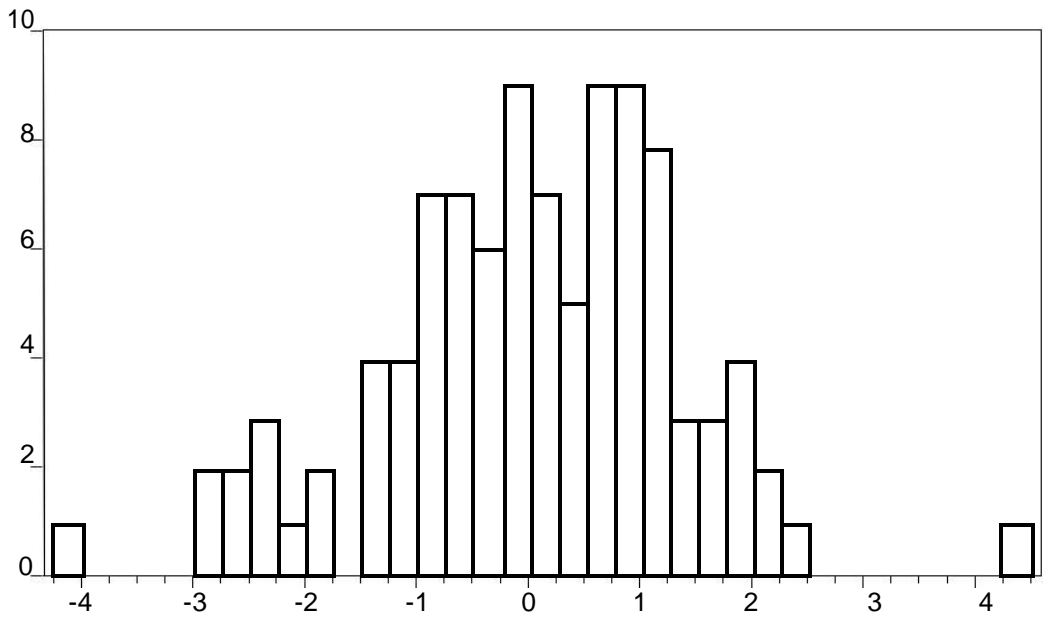

\begin{tabular}{|lr|}
\hline \multicolumn{2}{|l|}{ Series: Residuals } \\
Sample 1 100 \\
Observations 100 \\
\\
Mean & $-7.11 \mathrm{e}-17$ \\
Median & 0.027178 \\
Maximum & 4.296233 \\
Minimum & -4.029112 \\
Std. Dev. & 1.344113 \\
Skewness & -0.267933 \\
Kurtosis & 3.692269 \\
& \\
Jarque-Bera & 3.193282 \\
Probability & 0.202576 \\
\hline
\end{tabular}

Berdasarkan gambar di atas, bahwa nilai Jarque Berra yaitu $(3,193282)<X^{2}$ tabel $(123,22522)$ dan hasil probabilitas yaitu $(0,202576)>0,05$. Maka dapat disimpulkan bahwa residual berdistribusi normal.

\section{Uji Multikolinieritas}

Adanya hubungan antara beberapa atau semua variabel yang menjelaskan dalam model regresi. Jika dalam model terdapat multikolinieritas maka model tersebut memiliki kesalahan standar yang besar sehingga koefisien tidak dapat ditaksir dengan ketepatan tinggi. Multikolinearitas dalam penelitian ini dideteksi dengan menggunakan Auxilliary Regresion yaitu membandingkan besar nilai $R^{2}$ model utama dengan $R^{2}$ variebel-variabel independenya secara partial. Jika $R^{2}$ model utama lebih besar daripada $R^{2}$ variabel- variabel independennya maka tidak terjadi multikolinearitas (Gujarati,1995). Hasil uji multikolinieritas dapat dilihat pada gambar berikut:

\section{Hasil Uji Multikolinieritas}

\begin{tabular}{|c|c|c|c|c|c|c|}
\hline & $\mathrm{X} 1$ & $\mathrm{X} 2$ & $\mathrm{X} 3$ & $\mathrm{X} 4$ & $\mathrm{X} 5$ & $\mathrm{X} 6$ \\
\hline $\mathrm{X} 1$ & 1.000000 & 0.636508 & 0.653084 & 0.437894 & 0.324821 & 0.570609 \\
\hline $\mathrm{X} 2$ & 0.636508 & 1.000000 & 0.822612 & 0.540588 & 0.399690 & 0.583637 \\
\hline $\mathrm{X} 3$ & 0.653084 & 0.822612 & 1.000000 & 0.534008 & 0.501506 & 0.638738 \\
\hline $\mathrm{X} 4$ & 0.437894 & 0.540588 & 0.534008 & 1.000000 & 0.499416 & 0.606685 \\
\hline $\mathrm{X} 5$ & 0.324821 & 0.399690 & 0.501506 & 0.499416 & 1.000000 & 0.505577 \\
\hline $\mathrm{X} 6$ & 0.570609 & 0.583637 & 0.638738 & 0.606685 & 0.505577 & 1.000000 \\
\hline
\end{tabular}


Berdasarkan hasil auxilliary regression, dapat disimpulkan bahwa semua $\mathrm{R}^{2}$ regresi pada persamaan tersebut lebih kecil dari 0,8 . Sehingga dalam model ini tidak terdapat adanya multikolinearitas

\section{Uji Heteroskedastisitas}

Untuk mendeteksi heteroskedastisitas dilakukan dengan menggunakan Uji White. Hasil pengujian serial heteroskedastisitas menunjukkan hasil sebagai berikut:

Hasil Uji Heteroskedastisitas

\begin{tabular}{|lr|ll|}
\hline \multicolumn{4}{|c|}{ Heteroskedasticity Test: White } \\
\hline F-statistic & 1.058257 & Prob. F(27,72) & 0.4107 \\
Obs*R-squared & 28.41017 & Prob.Chi-Square(27) & 0.3901 \\
Scaled explained SS & 33.07715 & Prob. Chi-Square(27) & 0.1945 \\
\hline
\end{tabular}

Dengan uji white, dibandingkan Obs*Rsquared dengan X (chi-squared) table. Jika nilai Obs*Rsquared lebih kecil daripada $\mathrm{X}$ table maka tidak ada heterokedastisitas pada model (Gujarati,1995). Pengecekan dengan menggunakan White Heterokedasticity test menyatakan bahwa hasil Obs*R-squared adalah 28,41017 lebih kecil dari $\mathrm{X}^{2}$ tabel yaitu sebesar 123,22522 yang berarti tidak ada masalah heterokedastisitas.

\section{Uji Hipotesis}

\section{Koefisien Determinasi $\left(\mathbf{R}^{2}\right)$}

Hasil koefisien determinasi $\left(\mathbf{R}^{2}\right)$ dari model yang menunjukkan seberapa besar kemampuan variabel independen dalam menjelaskan variabel dependen dapat dilihat berdasarkan hasil estimasi model sebagai berikut:

Hasil Koefisien Determinasi $\left(\mathbf{R}^{2}\right)$

\begin{tabular}{|l|r|r|r|r|}
\hline \multicolumn{5}{|c|}{ Model Summary } \\
\hline Model & \multicolumn{1}{|c|}{$\mathrm{R}$} & $\mathrm{R}$ Square & $\begin{array}{c}\text { Adjusted R } \\
\text { Square }\end{array}$ & Std. Error of the Estimate \\
\hline 1 & $.720^{\mathrm{a}}$ & .518 & .487 & 1.42011 \\
\hline \multicolumn{7}{|l|}{$\begin{array}{l}\text { a. Predictors: (Constant), Selera, Distribusi Pendapatan, Harga Barang } \\
\text { Tersebut, Pendapatan, Harga Barang Pengganti, Harga Barang Pelengkap }\end{array}$} \\
\hline
\end{tabular}

Berdasarkan output di atas diketahui nilai $\mathrm{R}$ Square sebesar 0,518, yang hal ini mengandung arti bahwa pengaruh harga barang tersebut, harga barang pengganti, harga barang pelengkap, pendapatan, distribusi pendapatan dan selera secara simultan terhadap permintaan kebutuhan pangan dan sandang adalah sebesar 51,8 \% sedangkan sisanya 48,2\% dijelaskan oleh variabel residual yaitu variabel yang berada di luar model, yang tidak dimasukkan ke 
dalam model. Faktor-faktor yang mempengaruhi permintaan kebutuhan pangan dan sandang pada perusahaan Ritel X Karawang dapat dijelaskan 51,8\% oleh variabel harga barang tersebut, harga barang pengganti, harga barang pelengkap, pendapatan, distribusi pendapatan, selera.

\section{Uji Statistik F}

Uji F dilakukan untuk mengetahui pengaruh secara simultan atau serentak dari variabel-variabel independen terhadap variabel dependen. Uji F digunakan untuk menunjukan apakah semua variabel bebas yang dimasukan ke dalam model mempunyai pengaruh secara bersama-sama terhadap variabel tak bebas.

Hasil Uji F

\begin{tabular}{|c|c|c|c|c|c|c|}
\hline \multicolumn{7}{|c|}{ ANOVA $^{a}$} \\
\hline \multicolumn{2}{|c|}{ Model } & $\begin{array}{l}\text { Sum of } \\
\text { Squares }\end{array}$ & df & Mean Square & $\mathrm{F}$ & Sig. \\
\hline \multirow[t]{3}{*}{1} & Regression & 201.357 & 6 & 33.559 & 16.641 & $.000^{b}$ \\
\hline & Residual & 187.553 & 93 & 2.017 & & \\
\hline & Total & 388.910 & 99 & & & \\
\hline
\end{tabular}

a. Dependent Variable: Permintaan Kebutuhan Pangan dan Sandang

b. Predictors: (Constant), Selera, Distribusi Pendapatan, Harga Barang

Tersebut, Pendapatan, Harga Barang Pengganti, Harga Barang Pelengkap

Berdasarkan output di atas diketahui nilai signifikansi untuk pengaruh harga barang tersebut, harga barang pengganti, harga barang pelengkap, pendapatan, distribusi pendapatan dan selera secara simultan terhadap permintaan kebutuhan pangan dan sandang adalah sebesar 0,000 $<0,05$. Nilai f hitung adalah 16,641, sedangkan nilai f tabel dari derajat kebebasan (df) dengan numerato $(\mathrm{K}-1)$ dan denumerator $(\mathrm{N}-\mathrm{K})$, yaitu df $(6,94)$ dengan nilai $2,197(5 \%)$. Berarti nilai $\mathrm{f}$ hitung lebih besar daripada nilai f tabelnya, sehingga menerima hipotesis alternative $\mathrm{H}_{1}$ dan menolak hipotesisi $\mathrm{H}_{0}$. Ini berarti terdapat pengaruh harga barang tersebut, harga barang pengganti, harga barang pelengkap, pendapatan, distribusi pendapatan dan selera secara simultan terhadap permintaan kebutuhan pangan dan sandang.

\section{Uji Statistik t}

Uji statistik t dilakukan untuk melihat seberapa jauh pengaruh satu variabel bebas secara individual dalam menerangkan kondisi variabel terikat. Dari hasil uji t, pengaruh variabel bebas terhadap variabel terikat adalah sebagai berikut: 
Hasil Uji t

\begin{tabular}{|c|c|c|c|c|c|c|}
\hline \multicolumn{7}{|c|}{ Coefficients $^{a}$} \\
\hline & & \multicolumn{2}{|c|}{ Unstandardized Coefficients } & \multirow{2}{*}{$\begin{array}{c}\text { Standardized } \\
\text { Coefficients } \\
\text { Beta } \\
\end{array}$} & \multirow[b]{2}{*}{$\mathrm{t}$} & \multirow[b]{2}{*}{ Sig. } \\
\hline \multicolumn{2}{|c|}{ Model } & $\mathrm{B}$ & Std. Error & & & \\
\hline \multirow[t]{7}{*}{1} & (Constant) & 1.984 & .905 & & 2.193 & .031 \\
\hline & Harga Barang Tersebut & -.099 & .135 & -.094 & -.734 & .465 \\
\hline & Harga Barang Pengganti & .293 & .171 & .281 & 1.711 & .090 \\
\hline & Harga Barang Pelengkap & .273 & .188 & .259 & 1.455 & .149 \\
\hline & Pendapatan & -.112 & .103 & -.114 & -1.094 & .277 \\
\hline & Distribusi Pendapatan & .112 & .131 & .087 & .852 & .397 \\
\hline & Selera & .336 & .108 & .352 & 3.113 & .002 \\
\hline
\end{tabular}

a. Dependent Variable: Permintaan Kebutuhan Pangan dan Sandang

a. Pengaruh variabel harga barang tersebut (X1) terhadap permintaan kebutuhan pangan dan sandang pada perusahaan Ritel X Karawang (Y). Nilai t hitung adalah $-0,734$, sedang nilai $\mathrm{t}$ tabel adalah 1,989. Tanda negatif menunjukkan variabel harga barang tersebut terhadap permintaan kebutuhan pangan dan sandang pada perusahaan Ritel X Karawang bersifat negative. Nilai signifikansi sebesar 0,465, berarti variabel harga barang tersebut tidak signifikan terhadap permintaan kebutuhan pangan dan sandang pada perusahaan Ritel X Karawang.

b. Pengaruh variabel harga barang pengganti (X2) terhadap permintaan kebutuhan pangan dan sandang pada perusahaan Ritel X Karawang (Y). Nilai t hitung adalah 1,711, sedang nilai t tabel adalah 1,989. Oleh karena itu nilai t hitung lebih kecil dari nilai t tabel maka hipotesis (H1) ditolak dan hipotesis nol (H0) diterima. Sehingga, variabel harga barang pengganti tidak terdapat pengaruh terhadap permintaan kebutuhan pangan dan sandang pada perusahaan Ritel X Karawang.

c. Pengaruh variabel harga barang pelengkap (X3) terhadap permintaan kebutuhan pangan dan sandang pada perusahaan Ritel X Karawang (Y). Nilai t hitung adalah 1,455 , sedang nilai t tabel adalah 1,989. Oleh karena itu nilai t hitung lebih kecil dari nilai t tabel maka hipotesis (H1) ditolak dan hipotesis nol (H0) diterima. Sehingga, variabel harga barang pelengkap tidak terdapat pengaruh terhadap permintaan kebutuhan pangan dan sandang pada perusahaan Ritel X Karawang.

d. Pengaruh variabel pendapatan (X4) terhadap permintaan kebutuhan pangan dan sandang pada perusahaan Ritel X Karawang (Y). Nilai t hitung adalah - 1,094, sedang nilai t tabel adalah 1,989. Tanda negative menunjukkan variabel pendapatan terhadap 
permintaan kebutuhan pangan dan sandang pada perusahaan Ritel X Karawang bersifat negative. Nilai signifikansi sebesar 0,277 , berarti variabel pendapatan tidak signifikan terhadap permintaan kebutuhan pangan dan sandang pada perusahaan Ritel X Karawang.

e. Pengaruh variabel distribusi pendapatan (X5) terhadap permintaan kebutuhan pangan dan sandang pada perusahaan Ritel X Karawang (Y). Nilai t hitung adalah 0,852, sedang nilai $\mathrm{t}$ tabel adalah 1,989. Oleh karena itu nilai $\mathrm{t}$ hitung lebih kecil dari nilai $\mathrm{t}$ tabel maka hipotesis (H1) ditolak dan hipotesis nol (H0) diterima. Sehingga, variabel distribusi pendapatan tidak terdapat pengaruh terhadap permintaan kebutuhan pangan dan sandang pada perusahaan Ritel X Karawang.

f. Pengaruh variabel selera (X6) terhadap permintaan kebutuhan pangan dan sandang pada perusahaan Ritel X Karawang (Y). Nilai t hitung adalah 3,113, sedang nilai t tabel adalah 1,989. Oleh karena itu nilai t hitung lebih besar dari nilai t tabel maka hipotesis (H1) diterima dan hipotesis nol (H0) ditolak. Sehingga, variabel selera terdapat pengaruh terhadap permintaan kebutuhan pangan dan sandang pada perusahaan Ritel X Karawang.

\section{KESIMPULAN}

Hasil penelitian ini menunjukkan faktor-faktor yang mempengaruhi permintaan kebutuhan pangan dan sandang pada Perusahaan Ritel X Karawang. Dari enam faktor yang diangkat menjadi variabel dalam penelitian ini (harga barang tersebut, harga barang pengganti, harga barang pelengkap, pendapatan, distribusi pendapatan dan selera) terbukti bahwa faktor-faktor tersebut secara simultan berpengaruh terhadap permintaan kebutuhan pangan dan sandang pada perusahaan Ritel X Karawang. Variabel harga barang tersebut, harga barang pengganti, harga barang pelengkap, pendapatan dan distribusi pendapatan tidak terdapat pengaruh terhadap permintaan kebutuhan pangan dan sandang pada perusahaan Ritel X Karawang. Untuk variabel selera terdapat pengaruh terhadap permintaan kebutuhan pangan dan sandang pada perusahaan Ritel X Karawang.

\section{REFERENSI}

\section{Buku:}

Arsyad, Lincolin. 1997. Ekonomi Mikro Ikhtisar Teori dan Soal Jawab, Edisi 2, BPFE, Yogyakarta.

Bilas, Richard A. 1994. Teori Mikro Ekonomi, Terjemahan. Jakarta: Erlangga. 
Boeree, C. George. 2006. Personality Theories. Yogyakarta: Primasophie. 5. Abraham H. Maslow. 1968. Toward a Psychology of Being, $2 d$ ed. New York: D. Van Nostrad

Ferdinand, Augusty. 2006, Metode Penelitian Manajeman, Pedoman Penelitian untuk Penulisan Skripsi, Tesis dan Disertasi Ilmu Manajeman, Edisi 2, Badan Penerbit Universitas Diponegonro, Semarang.

Gujarati, Damodar. 2003. Ekonometrika Dasar. Jakarta: Penerbit Erlangga.

Gilarso, T, 1993, Pengantar Ilmu Ekonomi, Penerbit Kanisus, Jakarta. Irawan Suhartono. 1999. Metode Penelitian Sosial. Bandung: Rosdakarya.

Ida, N. 2009. Pengantar Ekonomi Mikro. Universitas Muhamadiah Malang Press. Malang. Jess, Gregory Feist. 2012. Teori Kepribadian. Jakarta: Salemba Humanika. 2. Edward Kusumosuwihdo, S.1990. Sajian Dasa Dalam Pengantar Teori Ekonomi. Rineka Cipta. Jakarta

Maslow, Abraham H. 1964. Religion, Value, and Peak-Experiences. Columbus: Ohis State University Press. . 1986. Farther Reaches of Human Nature. New York: Orbis Book. Maurice Basset. 2006. On Dominace, Self Esteen and Self Actualization. Ann Kaplan:

Mudrajat, Kuncoro. 2001. Metode Kuantitatif Teori dan Aplikasi Untuk Bisnis dan Ekonomi, UPP AMP YKPN, Yogyakarta.

Nicholson, Walter dan Danny Hutabarat. 1991. Mikro ekonomi Intermediate dan Penerapannya.

Rosyidi, Suherman. 1998, Pengantar Teori Ekonomi Pendekatan Kepada Teori Ekonomi Mikro dan Makro, Penerbit PT. Raja Grafindo Persada, Jakarta.

Sukirno, S. 2008. Teori Pengantar Mikroekonomi (Edisi Ketiga). RajaGrafindo Persada. Jakarta.

Samuelson. 2001. Ilmu Mikro Ekonomi. Edisi 17. Jakarta : PT. Media Global Edukasi

Sarwono, Sarlito W. 2002. Berkenalan dengan Aliran-aliran dan Tokoh-tokoh Psikologi. Jakarta: Bulan Bintang.

TS, Suharno. 2006. Teori Mikroekonomi. Surakarta: Andi 
Widarjono, Agus. 2009. Ekonometrika Pengantar dan Aplikasinya. Yogyakarta :Ekonesia. Badan Pusat Statistik. Jawa Tengah Dalam Angka Berbagai Tahun Terbitan. Jawa Tengah

\section{Jurnal:}

Damianus Kilamase, et al. 2015. Analisis permintaan buah anggur pada pasar modern di kota Ambon. Universitas Patimura Ambon. Volume 3 No 3 Oktober 2015

Nenik, W , 2010. “Analisis Permintaan Sepeda Motor Matic Di Kota Semarang”. Jurnal Ekonomi dan Bisnis, Vol.8, No 1. Jakarta : Erlangga.

Arif Budiarto, et all. 2013. Analisis Faktor-Faktor Yang Mempengaruhi Permintaan Sepeda motor di kota semarang (studi kasus : PNS Kota Semarang. Volume 2 Nomor 3 Tahun 2013

\section{Penelitian :}

Marsito Sirait. 2007. "Analisis Faktor-Faktor Yang Mempengaruhi Permintaan Mobil Pribadi di Sumatera Utara”. Skripsi Sumatera Utara, Medan.

Rossita. 2001 . "Analisis faktor-faktor yang mempengaruhi permintaan terhadap mobil bekas di kotamadya medan”. Skripsi Universitas Sumatera Utara, Medan.

Lisda Yanti, Sulina Surika, et al. (2013). Analsis faktor-faktor yang mempengaruhi permintaan asuransi jiwa di kota makasar. Universitas Hasanudin Makasar.

Surya A Sitorus, et all. 2015. Analisis faktor-faktor yang mempengaruhi dan Penawaran Telur Ayam Ras (Studi Kasu : Pasar Petisah, Kecamatan Medan Petisah). Universitas Sumatra Utara

Intan Sari Zaitun Rahma. 2010. Analisis faktor-faktor yang mempengaruhi $\mathrm{P}$ e $\mathrm{r}$ m i n t a a $\mathrm{n}$ Perumahan Tipe Cluster (Studi Kasu Perumahan Taman Sari di Kota Semarang). Universitas Diponegoro Semarang

Ainul Mardhiyah. 2006. Analisis faktor-faktor yang mempengaruhi Permint a a n Perumahan di Kota Medan. Universitas Sumatra Utara

Neni Theresia Hasibuan. 2008. Analisis faktor-faktor yang mempengaruhi K o n s u m e n a k a n S y u r Organik ( S t u di Kas u s: Kon sumen S y u rorgan is kd i k o t a m e d a n. Universitas Sumatra Utara

\section{Internet:}

https://finance.detik.com/berita-ekonomi-bisnis/. Perluas Gerai di Karawang, PERUSAHAAN RITEL X Gelar Diskon Hingga 40\% Jumat (6V12V2013). 
https://id.linkedin.com/. Tentang PERUSAHAAN RITEL X di Indonesia (PT Trans Retail Indonesia) 08 Desember 2013 20:00 WIB

http://industri.bisnis.com/ Inilah Konsep Wajah Baru PERUSAHAAN RITEL X di Karawang. 2013 13:45 WIB

http://ekonomi.kompas.com. Hingga Akhir Tahun, Pertumbuhan Industri Ritel Diprediksi Melambat. Kompas.com - 13/09/2017, 15:24 WIB

https://bisnis.tempo.co/. Aprindo: Pertumbuhan Sektor Ritel 2017 Lebih Rendah dari 2016. 17 Oktober 2017 05:08 WIB

https://www.merdeka.com. Kondisi mengenaskan industri ritel, laba anjlok hingga gulung tikar. Kamis, 3 Agustus 2017 06:00 
Santi Pertiwi Hari Sandi 